$\stackrel{N / 2}{N}$

Global Journals Inc

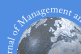

GLOBAL JOURNAL OF MANAGEMENT AND BUSINESS RESEARCH: B

ECONOMICS AND COMMERCE

Volume 21 Issue 2 Version 1.0 Year 2021

Type: Double Blind Peer Reviewed International Research Journal

\title{
Impact of Sales Volume (SAV) and Completely Knocked Down (CKD) in Automotive Industry on Economic Growth in Nigeria: 1987-2019
}

By Oyetunji David Olalere \& Muhammad Nuruddeen Isa

University of Abuja

Abstract- This study examined the impact of Sales Volume (SAV) and Completely Knocked Down (CKD) in Automotive Industry in Nigeria using time series data from 1987 to 2019. The objective of this research is to establish the Impact of Sales Volume (SAV) and Completely Knocked Down (CKD) in Automotive Industry on Economic Growth in Nigeria: 1987- 2019. Autoregressive Distributed Lag Model (ARDL) method was used. The findings from the study revealed that Sales volume (LSAV (-1)) at one lag period and Completely knocked down (LCKD) at lag value have significant impact on economic growth while Exchange rate (EXCR) is not significant. Interest rate and inflation rate appear to be statistically significant in determining economic growth at their contemporaneous values. Hence, we conclude that Sales Volume and Completely Knocked Down in Automotive Industry positively impacted on the economic growth in Nigeria over the period under study We therefore recommend that government should encourage an increase in sales volume for the economic growth status to keep enjoying positive contributions to the automotive sector in Nigeria.

GJMBR-B Classification: JEL Code: F43

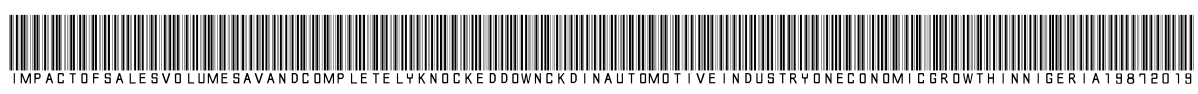

Strictly as per the compliance and regulations of:

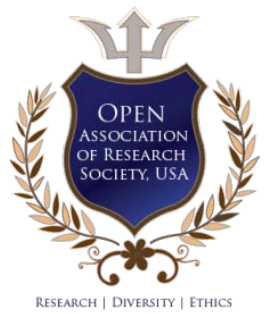

(C) 2021. Oyetunji David Olalere \& Muhammad Nuruddeen Isa. This is a research/review paper, distributed under the terms of the Creative Commons Attribution-Noncommercial 3.0 Unported License http://creativecommons.org/licenses/by-nc/3.0/), permitting all non-commercial use, distribution, and reproduction in any medium, provided the original work is properly cited. 


\title{
Impact of Sales Volume (SAV) and Completely Knocked Down (CKD) in Automotive Industry on Economic Growth in Nigeria: 1987-2019
}

\author{
Oyetunji David Olalere ${ }^{\alpha} \&$ Muhammad Nuruddeen Isa ${ }^{\sigma}$
}

\begin{abstract}
This study examined the impact of Sales Volume (SAV) and Completely Knocked Down (CKD) in Automotive Industry in Nigeria using time series data from 1987 to 2019. The objective of this research is to establish the Impact of Sales Volume (SAV) and Completely Knocked Down (CKD) in Automotive Industry on Economic Growth in Nigeria: 19872019. Autoregressive Distributed Lag Model (ARDL) method was used. The findings from the study revealed that Sales volume (LSAV (-1)) at one lag period and Completely knocked down (LCKD) at lag value have significant impact on economic growth while Exchange rate (EXCR) is not significant. Interest rate and inflation rate appear to be statistically significant in determining economic growth at their contemporaneous values. Hence, we conclude that Sales Volume and Completely Knocked Down in Automotive Industry positively impacted on the economic growth in Nigeria over the period under study We therefore recommend that government should encourage an increase in sales volume for the economic growth status to keep enjoying positive contributions to the automotive sector in Nigeria. It is recommended to government to ban importation of used vehicles, support vehicle finance scheme and create a more favourable enabling environment for enhanced patronage of locally manufactured vehicles.
\end{abstract}

\section{InTRODUCTION}

( ramatic upheavals have been occurring on the global automotive market for a number of years now. Up to around 2000, passenger cars were largely built and sold in the traditional automotive countries such as USA/Canada, the EU15 and Japan/Korea. Since then the balance has shifted fundamentally on the world market on both sides of the economic equation. While demand in the passenger cars appears largely saturated the markets of other regions especially the so-called emerging economies are enjoying strong growth on wheel (2011).

The Nigerian automotive market is mainly divided into two categories "New" and "Used". Used cars form a sizable portion of total imports. The new car segment's profit margin is being eroded by the increasing grey import and patronage as majority of Nigerians have limited means to buy new vehicle from authorized sources. The automotive industry in Nigeria Author a: (Ph.D.) National Automotive Design and Development Council Headquarters, Abuja. e-mail: olaleredavid.do@gmail.com Author o: (Ph.D.) Department of Economics, Faculty of Social Science, University of Abuja, Abuja.e-mail: isa_kn@yahoo.com dates back to the early 1960s, when private companies pioneered the establishment of local automotive assembly plants using completely/semi knocked-down parts. The federal government became involved in local automotive production 10 years later after concluding agreements with automobile manufactures in Europe. At that period, the automotive manufacturing plants had installed capacity of 108,000 cars, 56,000 commercial vehicles, 10, 000 tractors, 1,000,000 motorcycles and $1,000,000$ bicycles annually. Assuming the industry worked at full capacity, it could provide over 300,000 different jobs, (Nigeria Automobile Council 2009). However, as the country grew into an oil dependent economy in the late 1970s, and the government policy on importation became flexible, automotive manufacturing became difficult and local manufacturing plants could not bear the growing high cost of production and lack of government patronage. As a result, capacity utilization in the automotive industry over the years dropped below expectation with vehicle manufacturing below 10 percent (Nigeria Automobile Council 2009).

In order to revive the automotive industry, federal government established the National Automotive Council (NAC) now National Automotive Design and Development Council (NADDC) to ensure the survival and growth of the Nigerian automotive industry using local, human and material resources. The overall goal was to enhance the industry's contribution to the national economy in terms of regulating the production of automotive in the country. Unfortunately, due to a number of factors, including globalization of the automotive market and the impact of the second used car imports, the capacity utilization in the subsector, which was $90 \%$ in 1981 , is reduced to $10 \%$ in automotive assembly and $40 \%$ in components manufacturing, (Onoja, 2011).

National Automotive Council (2007) stated that the total vehicular supply (local product plus imports) was over a million units, about $80 \%$ of which were used. There is therefore a scope for new investment in the manufacture of low cost vehicle. Manufacturing Association of Nigeria (2005) opined that total vehicular import stood at 5,1525 units. In 2002 available records show that total import was 114,463 as against registered 
$1,073,146$ registered numbers in 2002, it was 223,664 units as against 702,487 registered numbers.

Since the National Automotive Industry Plan (NAIDP) was announced by the Federal Government in October 2013, the Nigerian automotive industry has witnessed serious interest from global and local automotive brands in setting up and doing business in a very promising sector and this has been a welcome development. Meanwhile, the Nigeria automotive industry should begin to look beyond assemblage of primary production, manufacturing and exportation because we are still trailing behind in consideration of our production capacity, availability of raw materials, political will, technological know-how and market (Jalal, 2014). Government should be applauded for putting in place the National Automotive Industry plan (NAIDP) as this has proactively charted a course for a proper auto policy frame work in the country, shortly before this policy was put in place in 2013, Nigeria and Bangladesh were the only countries in the top 10 by population without a developed automotive road map. The auto sector is a key component in the Nigerian Industrial Revolution Plan (NIRP), the NIRP is a 5-years programme developed by the Ministry of industry, Trade and Investments to help diversify the country's economy and revenue through industry and to increase manufacturing's contribution to GDP to at least 6\% this year and finally above $10 \%$ by year 2020 and the automotive industry has been classified strategic in this quest. The government believes that Nigeria is well positioned to be a major assembly hub for the International auto companies due to our existing installed auto capacity, large labour force and significant local demand and also a strategic location for export hence government is taking steps to making sure the industry takes its pride of place by providing the necessary regulations, working business environment and even funding in some quotas to support in production and to large their sale margin(Balarabe, 2013).

International automotive companies that are looking at expanding their market base are already stationing in Nigeria because of the massive investment opportunity the country is providing, within a space of four months after the policy was put in place by government and private investment. Arising from this, interest soared to an unexpected level with the announcement of plans by some reputable Original Equipment Manufacturers (OEMs) to establish their assembly plants in Nigeria. It took several years for some automobile manufacturing countries, like South Africa, to attract the level of attention and interest Nigeria got within four months of establishing the auto policy, rather than go to each of the OEMs to convince them to come, like South Africa did, they are lining up to come to Nigeria. It is however realistic to stress that no meaningful economic growth, wealth creation, employment generation and poverty reduction can be achieved in any country without a robust manufacturing sector which is the real sector of the economy.

However, we should nonetheless be grateful for the kind of interest the sector is already generating. It is a known fact that all over the world, big car manufacturers such as Nissan, GM, Toyota, VW produce only $30 \%$ of over 2000 parts of the vehicle components outsourcing the remaining $70 \%$ to component suppliers to provide thereby creating an avenue for growing local production capacity as well as creating direct employment. It is therefore interesting at this point to look at government's effort in reestablishing the sector, private initiatives in taking advantages of the conducive environment provided by government in support for CKD and to increase sale volume of vehicles in Nigeria, (Odetoro, 1999).

The Nigerian vehicle market, as it is, can support an indigenous automotive industry. National Automotive Council (NAC) had put some policies in place to improve, develop and sustain the market for local automotive industry. According to National Automotive Council (2014), about three quarters of the vehicles sold in Nigeria are used cars, due to the relatively low purchasing power of many Nigerians, as well as a taste for big cars and SUVs. However, vehicle manufacturers have designed strategies for producing affordable vehicle models. For instance, Nissan has reintroduced the Datsun brand as a low cost vehicle for developing countries. They launched it in India in early August and are looking for a manufacturing base to produce it for African countries. Nigeria has the opportunity to be that manufacturing base. The Nigerian auto strategy is to encourage OEMs to focus primarily on assembly of lower end less expensive models in Nigeria, which can be purchased within the same price range of existing used vehicles imported into the country that are typically priced around NGN 1.2 million to NGN 1.5 million. The auto development plan therefore expects higher-end expensive models will continue to be imported into the country, in the initial phase.

The established OEMs usually have vehicle financing schemes in the countries where they operate. NAC will work with OEMs to establish domestic dealership networks, setup captive finance operations, and integrate into the existing banking system in Nigeria. Some banks, including a specific bank that currently finances one third of vehicle purchases in South Africa, are already in a position to support this scheme and have expressed interest, National Automotive Council (2014).

Also, NAC (2014), The Federal Government purchase of vehicles (N6 billion in 2013 budget) is a small percentage of annual vehicle purchase (N550 billion in 2012), patronage of locally produced vehicles provides an example and sends a strong signal to others, by indicating a mark of confidence in the 
industry. It also shows that government is serious about job and wealth creation and technological development. Hence, following the above background, the paper examined the impact of sales volume and CKD in automobile industry on economic growth in Nigeria. Therefore, following the introduction of this study, the remaining part of this paper is structured as thus; section 2 is the literature review, while section 3 presents the methodology used in the paper. Section 4 presents results and interpretations, while section 5 concludes the paper.

\section{il. Literature ReView}

Much of the efforts have been exerted by previous authors on the impact of industrial development on economic growth in various countries. These have remained an indelible insight on the evaluation of the sectorial impact of industrial development activities on economic growth. Hence, delving into a few of these studies is a way to go in understanding the trend on the subject matter. Bennett, Anyanwu \& Kalu-Alexanda (2015) investigated the effect of industrial development on Nigeria's economic growth 1973 - 2013. They employed PC Give 8.00 version statistical package to analyze these condary data that was collected from the National statistical bulletin. The results revealed that the influence of industrial output on economic growth is not statistically significant, though the sign obtained from its àpriori expectation is positively related to (economic growth) GDP but does not hold strong enough. Savings has a positive relationship and also a significant impact on the economy. Inflation has a negative relationship while net foreign direct investment is positively significant on the impact of economic growth. R-squared shows a $76 \%$ increase in GDP. Based on the findings, it is there forere commended that the government and its agencies should ensure political stability and also the implementation of strategic policies that will create fair playing grounds for foreign investors which will also improve the establishment of industries especially the manufacturing industries to encourage industrialization of Nigeria.

Also, Afolabi \& Laseinde (2019) examined the impact of manufacturing sector output on economic growth in Nigeria from 1981 to 2016. The study employed secondary data sourced from the Central Bank of Nigeria statistical bulletin for Autoregressive Distributed Lag (ARDL) model and the Granger causality techniques on RGDP, manufacturing capacity utilization (MCU), manufacturing output (LMO), government investment expenditure (GINVEXP), money supply (LM2) and interest rate (INR). Evidence of long-run and shortrun relationships among the variables was established. The results showed that MCU has a positive influence on RGDP while LMO also affects RGDP positively. It also showed that GINVEXP has negative effects on RGDP whereas LM2 influenced RGDP positively. Moreover, the result indicated a unidirectional causality between RGDP and MCU, LMO, and LM2. Based on the above, the study suggests the government should intensify efforts to promote socio-economic infrastructural, macroeconomic and institutional framework in Nigeria to provide a favourable environment for external and domestic institutions interactions; so harnessed mobilized funds effectively towards the productive manufacturing sector.

Opoku \& Yan (2018) examined the impact of industrialization on economic growth in Africa by employing data for the period1980-2014 from 37. African countries and the generalized method of moments method, the results showed two main interesting outcomes even though industrialization is very muchon the low in the region. First, their results affirm the hypothesis that industrialization is an important booster of economic growth. Second, trade openness further augments the effect of industrialization on economic growth. They also employed alternative measures of industrialization and perform subregional/sampling analyses and the results are shown to be robust across. Similarly, Ossadzifo (2018) analyzed the impact of the manufacturing sector one conomic growth through the role of human capital. His data covered Sub-Saharan African (SSA) countries from 1990 to 2015 and used fixed-effects, random-effects, and Hausman-Taylor estimators taking into account the unobservable characteristics of countries by including fixed effects or random effects in the model. The results show that the manufacturing sector through its valueadded has a positive impact one conomic growth in SSA countries. Also, the interacting models show that the quality of human capital is an accelerator of the role of the manufacturing sector. The coefficient of the catchup term is negative and significant in all models indicating that countries with a larger productivity gap relative to China are developing faster than countries closer to China.

Given some of the accounts of literature on industrial development and economic growth presented above, various attempts have also been made to look at sectoral analysis (impact of Automobile Industry on economic growth). Singh (2017) analyzed the growth pattern and economic impact of the automobile industry on the Indian economy. The research study was conducted based on primary as well as secondary sources of data and information published by several governmental and private institutions namely SIAM (Society of Indian Automobile Manufacturers), DIPP (Department of Industrial Policy and Promotion), IBEF (India Brand Equity Foundation), BCG (The Boston Consulting Groups), Ernst \& Young, etc. Data were analyzed using a statistical tool like average, Percentage, CAGR (Compound Annual Growth Rate), AAGR (Average Annual Growth Rate), correlation, trend 
analysis line and bar graph, etc. All variables Exports, $\mathrm{FDI}$, Employment from the automobile industry have a positive impact on the growth of the economy. As a major employment and export generator, GDP contributor, FDI earner, the automobile industry is instrumental in shaping the country's economy.

Also, Saberi (2018) analyzed the role of the automobile industry in the economy of developed countries. The work reflects the extremely high role of the automotive industry in GDP growth and employment generation, the ability of the automotive industry to form a taxable base and revenues of the state budget, As well as the role of the automobile industry in the development of auxiliary industries and the stimulation of scientific and technological progress. Using explorative and descriptive analysis, the study found that the automotive industry contributes to the expansion of the taxable base and revenues of the state budget, develops auxiliary branches, influences scientific and technical progress, testifies to the level of solvent demand and the standard of living of the population of the country and much more. Thus, the effective functioning and development of the auto motive industry are important not only economic but also social significance for any country.

Luo (2005) Carried out a study on the factors affecting sale and production of automotive industry in China. The study discovered that almost all the major global car companies have entered the Chinese automotive market, and more considerably diversified car models have been introduced, in comparison with that oligopoly era before 2005 when there were very few models available. These changes have increased the competition in the domestic market, and driven the companies, including the state-owned firms. Therefore, the study advised the automotive industries to improve their product quality and design, decrease costs, and lower the price in order to increase their sales volume. Lily (2006) The Chinese automotive industry market change. The study revealed that automotive market grew rapidly from December 2001 to 2002, a growth that has been described as "gushing sales". The Chinese people's passion for cars has gathered speed with total vehicle sales reaching 3.38 million in 2002 (up 1 million over 2001), a surge of $37 \%$. In the first half of 2003 , vehicle sales were 2.08 million and are expected to top 4 million by the end of the year 2003. The result forecast that the China auto industry will grow by 47\% in 2004.

Hence, the conclusion that could be drawn from the above is that there is limited work in the area of automobile industry and economic growth, while from the available ones, only Pehlivanoğlu \& Riyanti (2018) considered sales in the automobile industry as one of the two main objectives of this study. He examined the macroeconomic effect of six variables on automobile sales in the top four automobile production countries. These variables are real GDP, GDP per capita, automobile production, inflation, gasoline price, and exchange rate; and the countries selected are China, USA, Japan, and Germany that has the first four highest automobile production countries in the world. The findings show that real GDP, car production, gasoline price have a positive impact on car sales while the change in GDP percapita, inflation, and exchange rate causes the opposite. Some variables in this research based on findings are inconsistent with the previous findings done by other researchers. While for those top countries GDP percapita and gasoline price have different effects on automobile sales. The reason for that situation is because GDP percapita that reflects fluctuation of income perpeople of those countries have no significant effect on the number of automobile sales. Therefore, it is very conspicuous that, to the best of our knowledge, no other study has looked at the impact of sales volumes in the automobile industry as well as Completely Knocked Down (CKD) on economic growth in Nigeria which represents the gap this study seeks to fill.

\section{ili. ReseArCH Method}

\section{a) Model Specification}

The model for this study is adapted from the work of Luo (2005) who carried out a study on the factors affecting sale and production of automotive industry in China. The model is modified by including some variables such as Sales Volume (SAV), Completely Knocked Down (CKD) in automotive industry in Nigeria.

$$
R G D P=f(S A V, C K D s, E X C R, I N T R \& I N F R)
$$

Equation 1 can be transformed into an econometrics model as thus;

$$
R G D P_{t}=\alpha_{0}+\alpha_{1} S A V_{t}+\alpha_{2} C K D s_{t}+\alpha_{3} E X C R_{t}+\alpha_{4} I N T R_{t}+\alpha_{5} I N F R_{t}+\mu_{t} \ldots \ldots \ldots \ldots . .2
$$

Where; $R G D P$ is Real Gross Domestic Product, $S A V$ is the Sales Volume from Automotive Industry; CKDs is Completely Knock Down; EXCR is Exchange Rate; INTR is Interest Rate; INFR is Inflation Rate and $\mu$ is the Error Term. Based on the the oretical framework and results from the empirical review, it is expected that $\alpha_{1}$ and $\alpha_{2}>0, \alpha_{4}$ and $\alpha_{5}<0$, while $\alpha_{3}>$ or $<0$.

\section{b) Estimation Techniques}

\section{i. ARDL Model}

ARDL model enables the study to test for Cointegration among the variables in the model through the help of Bound Test. This is done in order to ascertain the level of long run relationship among the variables in 
the model. The Autoregressive Distributed Lag (ARDL)

version of the model is formulated as follows:

$$
\begin{aligned}
& R G D P_{t}=a_{0}+\sum_{i=1}^{a}\left(\partial_{0} \operatorname{RGDP}_{\mathrm{t}-1}\right)+\sum_{\mathrm{i}=0}^{\mathrm{b}} \partial_{1} \mathrm{SAV}_{\mathrm{t}-1}+\sum_{\mathrm{i}=0}^{\mathrm{b}} \partial_{2} \mathrm{CKDs}_{\mathrm{t}-1}+\sum_{\mathrm{i}=0}^{\mathrm{c}} \partial_{3} \mathrm{EXCR}_{\mathrm{t}-1}+\sum_{\mathrm{i}=0}^{\mathrm{d}} \partial_{4} \mathrm{INTR}_{\mathrm{t}-1}+\sum_{\mathrm{i}-0}^{\mathrm{e}} \partial_{5} \mathrm{INFR}_{\mathrm{t}-1} \\
& +\partial_{6} \Delta \mathrm{RGDP}_{\mathrm{t}-1}+\partial_{7} \Delta \mathrm{SAV}_{\mathrm{t}-1}+\partial_{7} \Delta \mathrm{CKDs}_{\mathrm{t}-1}+\partial_{8} \Delta \mathrm{EXCR}_{\mathrm{t}-1}+\partial_{9} \Delta \mathrm{INTR}_{\mathrm{t}-1}+\partial_{10} \Delta \mathrm{INFR}_{\mathrm{t}-1} \\
& +U_{t}
\end{aligned}
$$

\section{ii. Error Correction Model (ECM)}

If the series are further co-integrated, then it will be most efficiently represented by an error correction method, which is used to tie short run behaviour of the

$$
\Delta Y_{t}=\alpha_{0}+\alpha_{1} \Delta X_{t}+\alpha_{2 t-1}+\varepsilon_{t}
$$

Where: $\Delta$ denotes the first difference,

$U_{t}$ is the one period lag value of the residual from the regression equation; $\alpha$ the empirical estimate of the equilibrium term and $\varepsilon$ is the error term. The variables to its long-run values. Engel and Granger (1987) stipulated that the ECM will correct disequilibrium error and is of the form:

$$
\begin{aligned}
R G D P_{t}=a_{0}+\sum_{i=1}^{a}\left(\partial_{0} \mathrm{RGDP}_{\mathrm{t}-1}\right)+\sum_{\mathrm{i}=0}^{\mathrm{b}} \partial_{1} \mathrm{SAV}_{\mathrm{t}-1}+ & \sum_{\mathrm{i}=0}^{\mathrm{b}} \partial_{2} \mathrm{CKDs}_{\mathrm{t}-1}+\sum_{\mathrm{i}=0}^{\mathrm{c}} \partial_{3} \mathrm{EXCR}_{\mathrm{t}-1}+\sum_{\mathrm{i}=0}^{\mathrm{d}} \partial_{4} \mathrm{INTR}_{\mathrm{t}-1}+\sum_{\mathrm{i}-0}^{\mathrm{e}} \partial_{5} \mathrm{INFR}_{\mathrm{t}-1} \\
& +\mathrm{ECM}_{t-1}+U_{t} \ldots \ldots \ldots \ldots \ldots \ldots \ldots \ldots \ldots \ldots \ldots \ldots \ldots \ldots \ldots \ldots \ldots \ldots \ldots \ldots \ldots \ldots \ldots \ldots \ldots \ldots \ldots \ldots \ldots \ldots \ldots \ldots \ldots \ldots \ldots \ldots \ldots \ldots \ldots \ldots \ldots \ldots \ldots \ldots \ldots \ldots \ldots \ldots
\end{aligned}
$$

unrestricted ECM model was used from which we obtain efficient lag-length necessary for estimation for ARDL model thus:

a) Descriptive Statistics

\section{Results and Discussion}

Table 4.1: Descriptive/Summary Statistics

\begin{tabular}{|c|c|c|c|c|c|c|}
\hline & GDP & SAV & CKD & EXCR & INTR & INFR \\
\hline Mean & 36370.69 & 4896.758 & 4087.000 & 343.9815 & 18.98030 & 19.87273 \\
\hline Median & 13301.56 & 5167.000 & 3866.000 & 402.2500 & 17.98000 & 12.22000 \\
\hline Maximum & 153624.6 & 13307.00 & 12641.00 & 787.9800 & 29.80000 & 72.84000 \\
\hline Minimum & 249.4391 & 458.0000 & 89.00000 & 16.35000 & 13.54000 & 4.070000 \\
\hline Std. Dev. & 43844.48 & 3600.183 & 3482.909 & 240.2236 & 3.426449 & 18.33461 \\
\hline Skewness & 1.125983 & 0.599728 & 0.670600 & -0.075235 & 1.503383 & 1.602969 \\
\hline Kurtosis & 3.119992 & 2.628453 & 2.873655 & 1.572391 & 5.117151 & 4.200904 \\
\hline Jarque-Bera & 6.992910 & 2.168020 & 2.495325 & 2.833475 & 18.59408 & 16.11528 \\
\hline Probability & 0.030305 & 0.338236 & 0.287175 & 0.242504 & 0.000092 & 0.000317 \\
\hline Sum & 1200233. & 161593.0 & 134871.0 & 11351.39 & 626.3500 & 655.8000 \\
\hline Sum Sq. Dev. & $6.15 \mathrm{E}+10$ & $4.15 \mathrm{E}+08$ & $3.88 \mathrm{E}+08$ & 1846636. & 375.6977 & 10757.06 \\
\hline Observations & 33 & 33 & 33 & 33 & 33 & 33 \\
\hline
\end{tabular}

Source: Authors' Computation, 2020

Table 4.1 presents the descriptive statistics of the followings; GDP, SAV, CKD, EXCR, INTR and INFR. The total number of observations for each of the six variables is 33. GDP assumes the highest average value, followed by SAV, CKD, EXCR, INFR and INTR respectively. Considering the normality status of individual variable's data distribution, the Jarque-Bera tests show that GDP, INTR and INFR are not normally distributed given that the probability of Jarque -Bera tests for each of these variables are significant at $5 \%$ i.e less than 0.05, while the variables SAV, CKD and EXCR are normally distributed over the years under study as their Jarque-Bera probability results are greater than $0.05(5 \%)$ level of significance. In line with Jarque-Bera results, Kurtosis also suggests that GDP, INTR and INFR are platykurtic, while SAV, CKD and EXCR are mesokurtic.

\section{b) Unit Root Test}

Even though unit root test is not a pre-test requirement for bounds testing procedure of exploring co-integration or long-run relationship among the variables of interest which is suitable for mutually cointegrated variables, ordinary $\mathrm{I}(1)$ or ordinary $\mathrm{I}(0)$ 
variables, unit root test is still very necessary to examine and ensure that the stationarity property of the explained variable is not I(2) or beyond and the explicative variables are integrated of order zero and one i.e I(0) and I(1) to fulfill the condition provided Pesaran et al.
(2001). Sequel to the preceding conditions, ADF and PP techniques were employed to explore the stationarity properties of the variables in the specified model. The output of ADF and PP unit root tests are presented in table 4.2.

Table 4.1.2: Unit Root Test Result

\begin{tabular}{|c|c|c|c|c|c|c|}
\hline \multirow{2}{*}{ Variable } & \multicolumn{2}{|c|}{ Augmented Dickey-Fuller (ADF) Test } & \multicolumn{2}{c|}{ Phillip-Perron (PP) Test } \\
\cline { 2 - 7 } & Level & $1^{\text {st }}$ iff. & Status & Level & $1^{\text {st }}$ Diff. & Status \\
\hline LGDP & $-3.902595^{\star \star \star}$ & $-3.090387^{\star \star \star}$ & $\mathrm{I}(0)$ & $-3.495721^{\star \star \star}$ & $-3.068114^{\star \star \star}$ & $\mathrm{I}(0)$ \\
\hline SAV & -2.050041 & $-5.426909^{\star \star \star}$ & $\mathrm{I}(1)$ & -2.050041 & $-14.54290^{\star \star \star}$ & $\mathrm{I}(1)$ \\
\hline CKD & -1.445540 & $-5.767458^{\star \star \star}$ & $\mathrm{I}(1)$ & -1.335029 & $-11.01312^{\star \star \star}$ & $\mathrm{I}(1)$ \\
\hline EXCR & -1.544839 & $-5.491989^{\star \star \star}$ & $\mathrm{I}(1)$ & -1.546806 & $-5.491989^{\star \star \star}$ & $\mathrm{I}(1)$ \\
\hline INTR & $-4.174370^{\star \star \star}$ & $-3.224519^{\star \star}$ & $\mathrm{I}(0)$ & $-4.407250^{\star \star \star}$ & $-10.49160^{\star \star \star}$ & $\mathrm{I}(0)$ \\
\hline INFR & $-3.318211^{\star \star}$ & $-6.158048^{\star \star \star}$ & $\mathrm{I}(0)$ & $-2.949472^{\star}$ & $-8.612534^{\star \star \star}$ & $\mathrm{I}(0)$ \\
\hline \multicolumn{7}{|c|}{ Asymptotic Critical Values } \\
\hline 1\% & -3.484198 & -3.484198 & -3.484198 & -3.484198 \\
\hline 5\% & -2.885051 & -2.885051 & -2.885051 & -2.885051 \\
\hline 10\% & -2.579386 & -2.579386 & -2.579386 & -2.579386 \\
\hline
\end{tabular}

* implies significant at $1 \%$ level and **implies significant at $5 \%$ level

Source: Authors' computation, 2020.

Table 4.2 shows the stationarity properties of the variables in the specified model. Both Augmented Dickey-Fuller and PP Tests produced similar results and present the integrated order of the variables. GDP, INTR, and INFR are integrated of order Zero, while SAV, CKD, and EXCR are integrated of order one. These results confirm the suitability of the ARDL technique of dynamic analysis for the study. Furthermore, the results also justify the importance of the F-bounds cointegration test over other traditional cointegration tests method given that the variables are not integrated of the same order and none of them is integrated of order 2 or beyond.

\section{c) F-Bounds Test for Cointegration}

To test if the variables have a long-run relationship, the F- Bounds test will be performed. The test involves computing ARDL equation and analyzes if the coefficients for the one-period lagged variables i.e. $\eta j, j=0,1,2 . . p$ are jointly zero. Thus, the following hypothesis test will be performed:

$H 0: \eta j=0 \forall j:$ A Long-run relationship does not exist $H 1: \eta j p=0$ for some $\mathrm{j}$ : A long-run relationships exist

A hypothesis test for each long-run coefficient will also be conducted to evaluate which of the indicators that have a significant relationship. As done in previous research, to reject or fail to reject the null hypothesis, the critical values, as used in Pesaran et al. (2001) will be followed. If the F-statistic falls above the critical values, we assume that there is a long-run relationship between the variables. If it falls below, we reject the notion of a long-run relationship and if it is in between we utilize we assume the result is inconclusive using the F-bounds test, therefore for further confirmation, we can result in using t-ratio.

Table 4.3: ARDL F-Bounds Test for Co-Integration Analysis

\begin{tabular}{|c|c|c|}
\hline $\mathrm{F}=70.32228$ & $\mathrm{~K}=\mathbf{5}$ & $\begin{array}{c}\text { Null-Hypothesis: No long-run } \\
\text { relationships exist. }\end{array}$ \\
\hline Critical Value & Lower Bound & Upper Bound \\
\hline $1 \%$ & 3.06 & 4.15 \\
$5 \%$ & 2.39 & 3.38 \\
$10 \%$ & 2.08 & 3.00 \\
\hline
\end{tabular}

Source: Author's Computation Using E-views software, version 10, 2020.

Table 4.3 shows the calculated F-statistic: 70.32228 (Significant at 0.01 and the marginal value with 4.15 as upper bound value). In line with the submission of Pesaran et al. (2001), the F-test is greater than the upper bound values at $1 \%, 5 \%$ and $10 \%$ respectively, hence the result suggests a rejection of the null hypothesis, and we can, therefore, conclude that there is a long-run relationship among the variables under consideration. Also, it justifies the validity of ARDL technique of analysis for this study.

\section{d) Model Lag Selection}

There are several methods to select the optimal or efficient lag structure for dynamic model analysis. In this study, the Akaike Information Criterion (AIC) will be employed in determining the lag structure for the 
specified model. According to Pesaran \& Shin (1998), AIC performs better in large samples (i.e more than 30 observations) than SIC.

Table 4.4: Lag Selection Criteria

\begin{tabular}{|c|c|c|c|c|}
\hline AlC & BIC & HQ & Adj. R-sq & Specification \\
\hline-2.812780 & -2.211430 & -2.616755 & 0.999209 & $\operatorname{ARDL}(1,1,1,2,0,2)$ \\
\hline-2.794222 & -2.146615 & -2.583119 & 0.999200 & $\operatorname{ARDL}(1,1,1,2,1,2)$ \\
\hline-2.790627 & -2.235535 & -2.609681 & 0.999183 & $\operatorname{ARDL}(1,1,0,2,0,2)$ \\
\hline-2.782389 & -2.181040 & -2.586365 & 0.999185 & $\operatorname{ARDL}(1,1,0,2,1,2)$ \\
\hline-2.774454 & -2.126847 & -2.563351 & 0.999184 & $\operatorname{ARDL}(2,1,0,2,1,2)$ \\
\hline-2.769337 & -2.075472 & -2.543155 & 0.999183 & $\operatorname{ARDL}(2,1,1,2,1,2)$ \\
\hline-2.762807 & -2.300231 & -2.612019 & 0.999135 & $\operatorname{ARDL}(1,2,1,0,0,0)$ \\
\hline-2.756646 & -2.340327 & -2.620936 & 0.999114 & $\operatorname{ARDL}(1,2,0,0,0,0)$ \\
\hline-2.755763 & -2.108156 & -2.544660 & 0.999169 & $\operatorname{ARDL}(1,2,1,2,0,2)$ \\
\hline-2.754002 & -2.106395 & -2.542898 & 0.999168 & $\operatorname{ARDL}(2,1,1,2,0,2)$ \\
\hline
\end{tabular}

Source: Authors' Computation Using E-views software, version 11, 2020.

From table 4.4, the AIC result shows that the efficient lag structure for the stated model is to follow $\operatorname{ARDL}(1,1,1,2,0,2)$ specification as the most suitable. However, in this stage of analysis, to avoid the problems of model misspecification, heteroskedasticity, and nonnormality of the variables jointly, Pesaran et al. (2001) suggest that the specification can still be adjusted where necessary.

e) ARDL Short-Run and Long-Run Estimation

i. Estimated Short-Run Error Correction Model Estimate

An error correction model for the selected ARDL Model is estimated. Table 4.5.1 presents the results of

Table 4.5.1: Error correction model specification of the ARDL $(1,1,1,2,0,2)$

Dependent Variable: D(LGDP)

\begin{tabular}{cccc}
\hline \hline Variable Coefficients & Std. Error & T- statistics & Prob \\
ECT(-1) -0.069332 & 0.002706 & -25.61916 & $0.0000^{* * *}$ \\
\hline \hline
\end{tabular}

Source: Authors' Computation Using Eviews software, version 11, 2020.

4.5.2ARDL Estimated Long-Run ARDL $(1,1,1,2,0,2)$

\begin{tabular}{|c|c|c|c|c|}
\hline \multicolumn{5}{|c|}{ The Regressand is LGDP } \\
\hline Variable & Coefficients & Std. Error & T-Statistics & Probability \\
\hline$L G D P(-1)$ & 1.069332 & 0.021550 & 49.62205 & $0.0000^{\star \star \star}$ \\
\hline$L S A V$ & -0.010434 & 0.032568 & -0.320373 & 0.7524 \\
\hline$L S A V(-1)$ & 0.069165 & 0.032525 & 2.126508 & $0.0475^{\star \star}$ \\
\hline$L C K D$ & 0.051055 & 0.021235 & 2.404223 & $0.0272^{\star \star}$ \\
\hline$L C K D(-1)$ & -0.027852 & 0.021818 & -1.276574 & 0.2180 \\
\hline$E X C R$ & $2.16 \mathrm{E}-05$ & 0.000121 & 0.178138 & 0.8606 \\
\hline$E X C R(-1)$ & 0.000186 & 0.000143 & 1.302004 & 0.2093 \\
\hline$E X C R(-2)$ & -0.000249 & 0.000121 & -2.064554 & $0.0537^{\star}$ \\
\hline$I N T R$ & 0.017024 & 0.004758 & 3.578150 & $0.0021^{\star \star \star}$ \\
\hline$I N F R$ & 0.004663 & 0.000945 & 4.934957 & $0.0001^{\star \star \star}$ \\
\hline$I N F R(-1)$ & 0.000249 & 0.000954 & 0.261176 & 0.7969 \\
\hline$I N F R(-2)$ & 0.001617 & 0.000925 & 1.747133 & $0.0977^{\star}$ \\
\hline$C \quad-1.536346$ & 0.392837 & -3.910897 & $0.0010^{\star \star \star}$ \\
\hline
\end{tabular}

Source: Author's Computation Using Eviews software, version 11, 2020.

4.5.3 Post-Estimation Test 
Table 4.5.3: Diagnostic Test Results

\begin{tabular}{|c|c|c|}
\hline Tests & F-Statistics & Probability \\
\hline Serial Correlation & 1.121713 & 0.3500 \\
\hline Specification & 0.000150 & 0.9904 \\
\hline Normality & 0.022360 & 0.988882 \\
\hline Heteroscedasticity & 0.611214 & 0.8062 \\
\hline
\end{tabular}

Source: Author's Computation Using Eviews software, version 10, 2020.

10

8

6

4

2

0

$-0.10$

$-0.05$

0.00

Figure 4.5.3 (A): Normality Test

$-10$

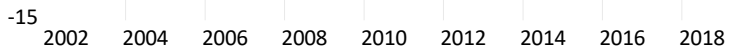

_ Cusum _.... $5 \%$ significance

Figure 4.5.3 (B): CUSUM Test

f) Interpretation of Results

The results presented in Table 4.5.2 shows the coefficients of the independent variables on the impact of Sales Volume and Complete Knocked Down in the automotive industry on economic growth in Nigeria. As a dynamic model with autoregressive property, the one period lag of log of gross domestic product (LGDP) shows a positive and significant impact on the current value of the LGDP, explicitly, a percentage increase in LGDP(-1) brings about $1.069332 \%$ change in LGDP. For the policy variables, one-period lag of log of Sales volume $(\operatorname{LSAV}(-1))$ and the contemporaneous value of the log of Complete knocked down (LCKD) are significant in determining the target variable; a percentage increase in $\operatorname{LSAV}(-1)$ and LCKD birth $0.069165 \%$ and $0.051055 \%$ change in the regress and, respectively. Among the control variables, the contemporaneous value of the Exchange rate (EXCR) is not significant, but its two-period lag is negatively

0.05

1.6

1.2

0.8

0.4

0.0

\begin{tabular}{|lc|}
\hline \multicolumn{2}{|l|}{ Series: Residuals } \\
Sample 1989 & 2019 \\
Observations & 31 \\
Mean & $3.95 \mathrm{e}-15$ \\
Median & 0.001662 \\
Maximum & 0.093949 \\
Minimum & -0.092653 \\
Std. Dev. & 0.039625 \\
Skewness & 0.048789 \\
Kurtosis & 2.911740 \\
Jarque-Bera & 0.022360 \\
Probability & 0.988882 ?
\end{tabular}

$-0.4$ $\begin{array}{llllllll}2002 & 2004 & 2006 & 2008 & 2010 & 2012 & 2014 & 2016 \quad 2018\end{array}$
Figure 4.5.3 (C): CUSUM of Squares Test

related to the target variable at a $10 \%$ level of significance; a unit increase in $\operatorname{EXCR}(-2)$ leads to a $0.000249 \%$ change LGDP. Furthermore, interest rate and inflation rate appear to be statistically significant in determining the target variable at their contemporaneous values. A unit increase in interest rate and inflation rate leads to $0.017024 \%$ and $0.004663 \%$ change in the log of GDP (LGDP).

From table 4.5.1, the magnitude of the estimated coefficient of the error correction term suggests a speed of adjustment to any disequilibrium in the short run. In other words, the estimated $\mathrm{ECM}_{\mathrm{t}-1}$ is equal to -0.069332 which states that the departure from the equilibrium is adjusted by $6 \%$ per annum. It is also negative, significant, and less than one which means that information from this can be relied upon for policy decisions.

The model was subjected to the post-estimation tests of serial correlation, heteroskedasticity, normality, 
and stability tests. Jarque Bera test for normality = 0.022360 ( $p=0.988882$; i.e. $p>0.05$ ); Breusch-Godfrey Serial Correlation LM Test $=1.121713(p=0.3500$, i.e. $p>0.05)$; Heteroskedasticity Test using BreuschPagan-Godfrey F statistic $=0.611214(p=0.8062$, i.e. $p>0.05)$; specification test using Ramsey RESET test estimated t statistic $=0.000150(p=0.9904$, i.e. $p>$ 0.05).

The post-estimation results imply that the model's residuals were normally distributed, devoid of a significant presence of serial correlation, free from heteroscedasticity threats, not fraught with a severe threat of multicollinearity and properly specified or not mis-specified. These properties are desirable properties of OLS models. Since our model exhibit all the desirable properties of OLS, we conclude that our model is very reliable for economic analysis and forecasting.

Also, the stability of the model is evidenced by the results of the stability test using CUSUM and CUSUM square tests as indicated in the diagram in figure 4.2.4 (B) and 4.2.5 (C). Since the residual plots did not fall outside the $5 \%$ significant boundaries, the estimates are deemed stable over the period.

\section{Conclusion and Recommendation}

In conclusion, the estimated model reveals that the target variables i.e Sales Volume and Completely Knocked Down are positively related to the economic growth in Nigeria over the period under study. However, it is noteworthy that the instantaneous effect of SAV is not statistically significant i.e, the current value of Sales Volume appears insignificant in determining current value. However, the one-period lag value of Sales volume is significant in determining the behavior of the economic growth in its current period but Completely Knocked Down in its contemporaneous value remains significant in explaining the economic growth.

There is no doubt that sales volume is keyed to the survival of the automotive industry. Many automotive companies opined that, average prices of vehicles would have been declining if they can make sales in volumes. Unfortunately, sales volumes are declining over the years leading to increasing average prices of vehicles due to unabsorbed overhead expenses. It becomes impossible to achieve economies of scales and deletion programme that would have increased local contents. There is even capacity underutilization. Due to rising prices, many cannot afford new vehicles and this results in buying used vehicles. The thriving automotive plants in 1970s have become moribund in few years past and turned to mere warehouses for used vehicles. Having discovered the nature of the relationship in the model, it is therefore recommended that government should encourage automotive sector in Nigeria to thrive through increase in sales volume and CKD so as to impact more on national economic growth leading to favourable balance of trade and payments. Furthermore, Completely Knocked Down should also be encouraged as its positive impact on the economic growth in Nigeria is significant. If government can review tariff regime in favour of CKD and against SKDs and fully built vehicles, ensure that vehicle finance scheme is established and functional so as to make people have access to credit facilities at a single digit rate, then sales volume will be boosted and economic growth in Nigeria through automotive industry shall be significant.

\section{References Références Referencias}

1. Afolabi, A., \& Laseinde, O. T. (2019). Manufacturing Sector Performance and Economic Growth in Nigeria. In Journal of Physics: Conference Series (Vol. 1378, No. 3, p. 032067). IOP Publishing.

2. Alhaji Balarabe Mainasara, (2013) 87 Years, National standard motors, Dogon-daji House, Sokoto, Kwamberu Area, Sokoto, 05-10-2013.

3. Alhaji Malamin Dan Kure (2012), 52 Years, Tokunbo Vehicles Trader, Gidan- Kanawa Area, Sokoto, 1505-2012.

4. Bennett, K. O. Anyanwu, U. N. \& Kalu-Alexanda, O. $\cup$ (2015). The effect of industrial development on economic growth (an empirical evidence in Nigeria 1973-2013). European Journal of Business and Social Sciences, 4(02), 127-140.

5. Chukwurah, D, Onwuka E, Okoye N, Dibua C, \& Ezeanyim, E (2016) Examined the influence of globalization on automobile sector of Nigeria (19902015). Journal of Business and Management (IOSRJBM). Volume 18, Issue 9.

6. David ward. (2011). Global Trends 2020 and Beyond Automobile Use, Environment \& Safety Challenges. Proceeding of Auto world Brussels 22nd, Belgium, June 2011.

7. Jalal, A. (2014) 'The Nigerian Automotive Industry Development Plan'. Nigerian Automotive Summit, Lagos, 16 June.

8. Jalal, Aminu. Investment Opportunities in Nigeria's Automotive Industry. Auto Component Parts Development in Nigeria. National Automotive Council. Vol. 1, 3.

9. Lily, I.Q (2006) a studyin changes in china automotive market in the world. The entry of China into the World Trade Organisation (WTO). Journal of International Marketing and Exporting, 5(1), pp. 59-71.

10. Luo, J. (2005). "The factors affecting sale and production of automotive industry in China", report, International Motor Vehicle Program.

11. National Automobile Council, Vol. 2 (2009).

12. National Automotive Council. Vol. 1, 3. June. 1999.

13. Nnamani, E Ajagu, Helen, E. \& Nnamani, S (2018) the study was on the effect of globalization on 
growth of automobile firms in Nigeria. International Journal of Management Research. Pp: 2394-4226), Volume 6.

14. Odetoro, W. K. (1999) Current Situation with Auto Component Parts Manufacturing Activities in Nigeria. Auto Component Parts Development in Nigeria. National Automotive Council. Vol. 1, 3. June.

15. Omobowale AO (2013). The Tokunbo Phenomenon and Second-hand Economy in Nigeria, Africa Development, Peter Lang, New York. 2013.

16. Onoja, E. (2011). Africa and the Challenge of Globalization: How Should the Continent Respond? Nigerian Journal of Economic and Financial Review, $6(2), 35-42$.

17. Onwheel (2011) Globalization and employment generation in Nigerian manufacturing sector. European journal of social sciences, 12 (4), 581-593.

18. Opoku, E. E. O., \& Yan, I. K.-M. (2018). Industrialization as driver of sustainable economic growth in Africa. The Journal of International Trade \& Economic Development, 1-27. doi:10.1080/096381 99.2018.1483416.

19. Ossadzifo, K. (2018). Industrialization and economic growth in Sub-saharan Africa: The role of human capital in structural transformation. Journal of Empirical Studies, 5(1), 45-54.

20. Pehlivanoğlu, F., \& Riyanti, R. (2018). Macroeconomic Effect on the Automobile Sales in Top Four Automobile Production Countries. Kocaeli Üniversitesi Sosyal Bilimler Dergisi, (35), 139-161.

21. Saberi, B. (2018). The role of the automobile industry in the economy of developed countries. International Robotics \& Automation Journal, 4(3), 179-180.

22. Singh, V. (2017). Growth of the automobile industry and its economic impact: An Indian perspective. International Journal of Commerce and Management Research, 3(8), 06-10. 